\title{
A NEW MACHINE FOR PRODUCING BUTTER TO SUIT SMALL PROJECTS
}

\author{
Badr, M. M. ${ }^{1}$
}

\author{
M. M. A. El-Sharabasy ${ }^{2}$
}

\begin{abstract}
The aim of the present study is to manufacture and evaluate batch butter churning machine for butter and buttermilk production from sweet or fermented cream. The new butter making machine consists of five main parts: power source, transmission system, collection cream vessel and cooling unit. The cooling unit consists of five parts: evaporator, expansion valve, condenser, fan, receiver tank, and compressor. Laboratory experiments were conducted to optimize cream loading ratio, churning time and churning temperature. While the churn machine performance was evaluated in terms of butter and buttermilk amounts, buttermilk fat percentage, churn efficiency, specific energy and operational cost of butter churn. The experimental results reveal that the churning machine is recommended to be used to give the highest butter production of $21.20 \mathrm{~kg} / \mathrm{h}$ with lower specific energy and operational cost of $23.11 \mathrm{~kW} . \mathrm{h} / \mathrm{Mg}$ and $188.21 \mathrm{L.E} / \mathrm{Mg}$, respectively at cream loading ratio of $45 \mathrm{~kg} / \mathrm{h}$, churning temperature of $6^{\circ} \mathrm{C}$ and churning time of 15 min under constant fan speed of $600 \mathrm{rpm}$.
\end{abstract}

\section{INTRODUCTION}

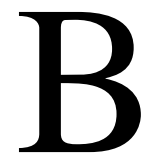
utter is essentially the fat of milk. It contains $81-85 \%$ fat, $14-16 \%$ water, $0.5-4.0 \%$ fat-free solids and $1.2 \% \mathrm{NaCl}$ in the case of salted butter. It is usually made from sweet cream. In the USA, Ireland and the UK, salt is usually added to it. Unsalted (sweet) butters are most commonly used in the rest of Europe. However, it can also be made from acidulated or bacteriologically soured cream. Well into the 19th century butter was still made from cream that had been allowed to stand and sour naturally. The cream was then skimmed from the top of the milk and poured into a wooden tub. Buttermaking was done by hand in butter churns. The natural souring process is, however, a very sensitive one and infection by foreign microorganisms often spoiled the result. Today's commercial buttermaking is a product of the knowledge and experience gained over the

\footnotetext{
${ }^{1}$ Lecturer of Agric. Eng., Fac. of Agric., Zagazig Univ., Egypt.

${ }^{2}$ Assist. Prof. of Agric. Eng., Fac. of Agric., Zagazig Univ., Egypt.
} 
years in such matters as hygiene, bacterial acidifying and heat treatment, as well as the rapid technical development that has led to the advanced machinery now used. The commercial cream separator was introduced at the end of the 19th century; the continuous churn had been commercialized by the middle of the 20th century. Changing whole milk to butter is a process of transforming a fat-in-water emulsion (milk) to a water-in-fat emulsion (butter). Whole milk is a dilute emulsion of tiny fat globules surrounded by lipoprotein membranes that keep the fat globules separate from one another. Butter is made from cream that has been separated from whole milk and then cooled; fat droplets clump more easily when hard rather than soft. However, making good butter also depends upon other factors, such as the fat content of the cream and its acidity (Wikipedia, 2013). The cream setting pan and dairy thermometer in combination will produce cream from 4 liters of milk. Depending on the fat content of the milk, approximately 0.5 liters of cream can be obtained from this and the minimum churn charge of 1 liter can be quickly separated. This can be used if no automatic cream separator such as (Disc Bowl Centrifuge) is available. Approximately $0.5 \mathrm{~kg}$ of butter can be made from 1.5 liters of cream in the churn. During the churning process it is necessary to drain of the buttermilk and washing water and a sieve is provided to strain out any butter particles to be returned to the churn. Scotch Hands are required to 'work' the butter into a solid mass after churning (FPET, 2013). Churning is essentially strong mechanical cream shearing which tears the membranes of the fat globules and facilitates coalescence of the globules. The cream "breaks" and tiny granules of butter appear. Prolonged churning results in a continuous fat phase. Foam build-up is also desirable since the tiny air bubbles, with their large surface area, attract some membrane materials. Some membrane phospholipids are transferred into the aqueous phase. Buttermilk, a milky, turbid liquid, separates out initially (it is later drained off), followed by the butter granules of approx. $2 \mathrm{~mm}$ diameter. These granules still contain $30 \%$ of the aqueous phase. This is reduced to $15-19 \%$ by churning. The finely distributed water droplets (diameter $10 \mu \mathrm{m}$ or less) are retained by the fat phase. Churning is mainly carried out in stainless steel vessels of different forms which rotate non-symmetrically. Continuously operated churns are also used with cream having a fat content of 32-38\% (sour cream butter) or 40-50\% (sweet cream butter). The machines are divided into churning, separation, and kneading 
compartments. In the churning compartment, a rotating impact wave causes butter granule formation. The separation compartment is divided into two parts. The butter is first churned further, resulting in the formation of butter granules of a larger diameter (Belitz et al., 2009). During churning, the cream is separated into butter grains and buttermilk in a churning cylinder, followed by draining of the butter milk and by processing of the butter grains and removal of the formed butter (Frede and Buchheim, 1994). The churning temperature is in the range from 10 to $15^{\circ} \mathrm{C}$. It has been argued that at temperatures above $13^{\circ} \mathrm{C}$, a relative high amount of the fat will be liquid. Consequently, the possibility to incorporate high amounts of water in the butter by continuous mixing (the next manufacturing step) is limited, as it results in a wet and leaky product. Churning at temperatures below $5^{\circ} \mathrm{C}$ results in such a high SFC that only a small amount of liquid fat can be squeezed out of the fat globules during churning. Thus, after a long churning time, very small butter grains are formed (Rønholt et al., 2013). Churning time is significantly affected by the cream cooling rate, fast-cooled cream having a longer churning time compared to slow-cooled. This tendency is considered to be a result of the large crystals formed by slow cooling, working as eroding agents penetrating the milk fat globule membrane. An increase in crystal size increases the degree of rupture of the milk fat globule membranes, thus facilitating phase inversion from oil-in-water to a water-inoil emulsion (Boode 1993 and Rønholt, 2012). With respect to rotational speed, the high shear rates applied break down the reversible and irreversible bonds within the crystal network, decreasing the hardness to about a quarter of the original value. As a consequence of the discontinued structure formation, milk fat-based products subjected to strong mixing have a more granular structure compared to products subjected to limited or no mixing. A short residence time, on the other hand, induces a stronger degree of supercooling. Consequently, smaller emulsion droplets are formed and coalescence is less likely to occur (Marangoni and McGauley, 2003). Butter made from cream held at $15.6^{\circ} \mathrm{C}$ and churned at $7.2^{\circ} \mathrm{C}$ contained more free liquid oil and was softer than butter held and churned at $7.2^{\circ} \mathrm{C}$. Generally, it is recommended that cream for winter butter be cooled to $10^{\circ} \mathrm{C}$ after pasteurization and held overnight between 10 and $12.8^{\circ} \mathrm{C}$ (Wright et al., 2001). 
So, the objectives of the present study are to construct a new batch butter churning machine to be suitable for making the butter from the cream, optimize some operating parameters: (cream loading ratio, churning time and churning temperature) affecting the performance of the constructed machine and evaluate the constructed machine from the economic standpoint.

\section{MATERIALS AND METHOD}

This study was carried out during the winter season of 2013 at Agricultural Engineering Department and Food Science Department, Faculty of Agriculture, Zagazig University to construct and evaluate the performance of a new butter churning machine for butter and buttermilk production from sweet or fermented cream.

\subsection{MATERIALS:}

2.1.1. Cream: The sweet cream used to buttermaking with the constructed churning machine was gathered from dairy in Abo Al-Akhdar village, Sharkia Governorate. The used cream has fat content of 30-35\% stored in the temperature of $4-8{ }^{\circ} \mathrm{C}$ along 10 days to take its acidity and structure since the good buttermaking depends on cream fat content and suitable stored temperature in adequate time.

2.1.2. The new constructed buttermaking machine: This machine was manufactured from low cost and local materials to overcome the problems of lower efficiency for buttermaking local machines and butter loss percentage in buttermilk. The buttermaking machine was manufactured specially for this work and constructed at a private workshop in Zagazig city, Sharkia Governorate as shown in Fig.1 and Photo 1. The constructed buttermaking machine consists of the two main parts as following:

2.1.2.1. Churning unit: The churning unit consists of the following parts:

- Butter pan: The butter pan was cylindrical in shape with $35 \mathrm{~cm}$ diameter and $26 \mathrm{~cm}$ length fixed on the main frame of the buttermaking machine to receive the sweet cream. The butter pan has an outlet to discharge the buttermilk after churning process.

- Fan: A flat fan with diameter of $16 \mathrm{~cm}$ and six feathers was located in the bottom of the butter pan and aside to facilitate the electric motor connection through a V-belt. The flat fan is considered the important part in the buttermaking machine which producing the butter from cream by the centrifugal force. 


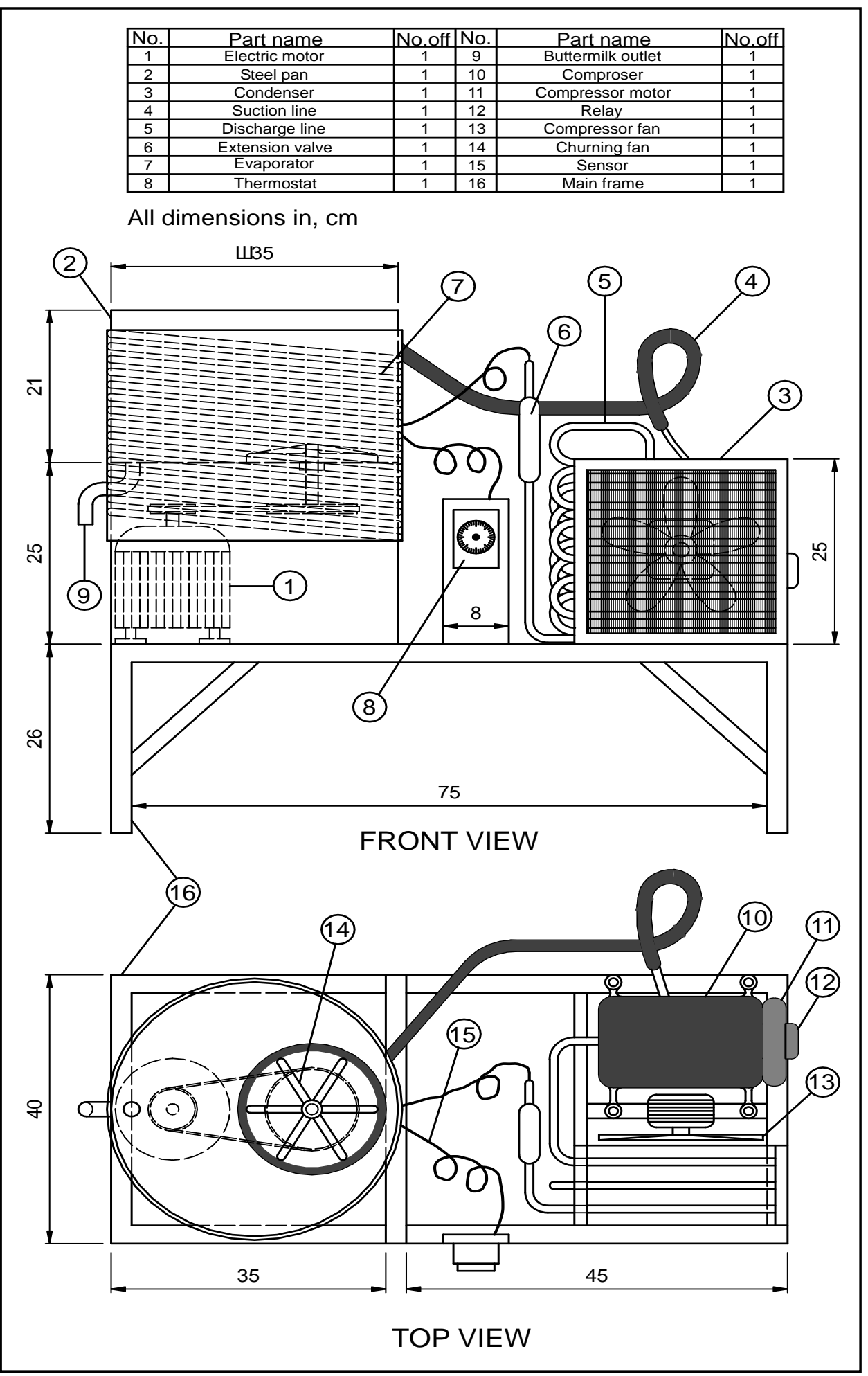

Fig.1: A front view and top view of the constructed churning machine.

Misr J. Ag. Eng., January 2014 


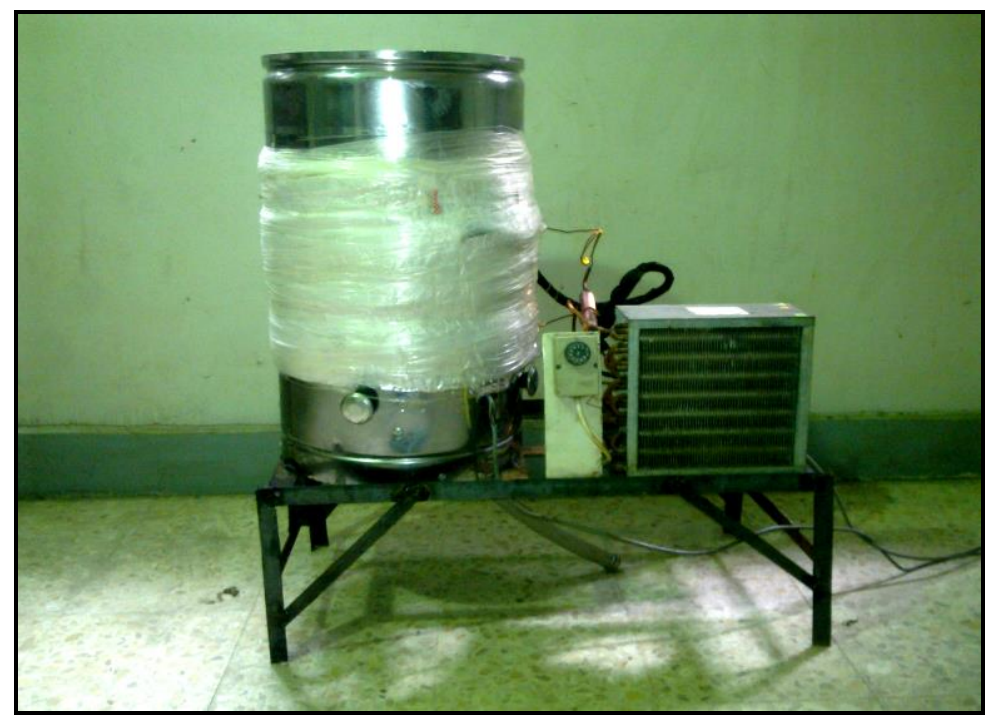

Photo.1. The constructed churning machine.

- Electric motor: A small electric motor with power of $0.33 \mathrm{hp}(0.24 \mathrm{~kW})$ and $1450 \mathrm{rpm}$ transported its rotating motion to the fan though a V-belt and two pulleys having diameters of $50 \mathrm{~mm}$ and $110 \mathrm{~mm}$ with reduction ratio of 1: 4.5 to gain the suitable fan rotating speed of $600 \mathrm{rpm}$.

2.1.2.2. Cooling unit: The cooling unit consists of the following parts:

- Compressor: A gas compressor is a mechanical device that increases the pressure of a gas by reducing its volume. A $0.33 \mathrm{hp}$ compressor was used to pressurize and transport liquids in the cooling unit during churning process (Fig.2).

- Condenser: is a unit used to condense vapor into liquid before interring to the extension valve (Fig.2).

- Evaporator: is a device used to turn the liquid form of a chemical into its gaseous form to reduce the temperature around the butter pan.

- Thermostat: is a component of a control system which senses the temperature of a churning process, so that the butter pan temperature is maintained near a desired set point. The thermostat does its work by switching cooling device on or off, or regulating the flow of a heat transfer fluid as needed, to maintain the correct temperature.

- Expansion valve: is a component in systems that controls the amount of refrigerant flow into the evaporator thereby controlling the superheating at 
the outlet of the evaporator. Thermal expansion valves are often referred to generically as "metering devices" (Fig.2).

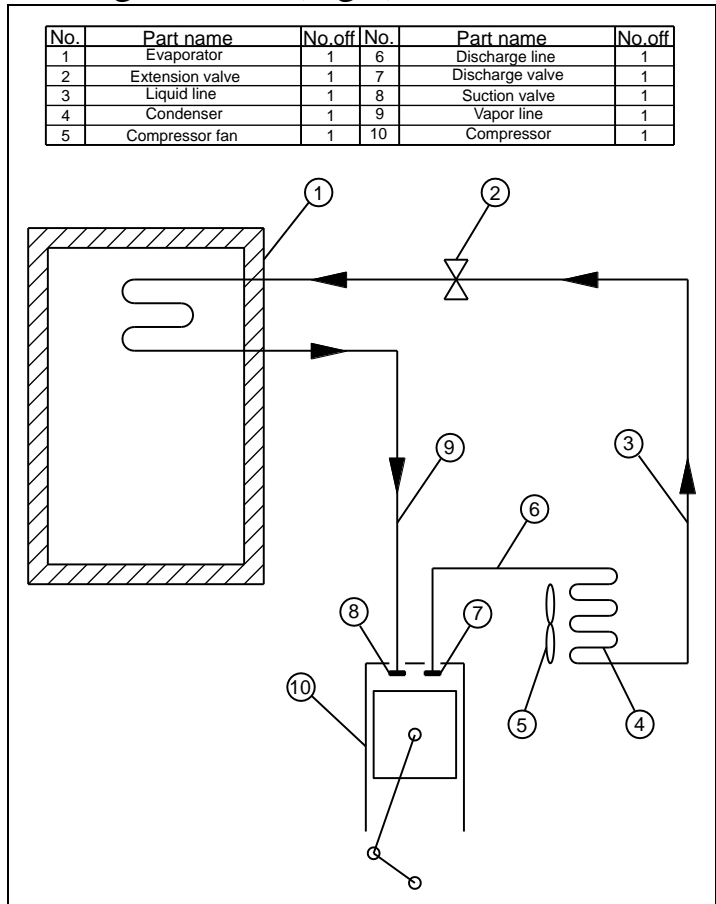

Fig.2. Schematic diagram of the cooling unit used for churning process.

\subsection{METHOD:}

\subsubsection{Preparing cream for churning:}

The required quantity of ripened cream is weighted. The temperature of cream is adjusted between 4 to $10{ }^{\circ} \mathrm{C}$ depending upon the season. This is called as churning temperature. If the temperature is low, the fat globules become harder and coal eases each other with difficulty resulting in the delayed churning. If higher temperature is used the butter produced will be soft, greasy, but the churning will be quick. The temperature is adjusted by adjusting cooling unit to the demanded temperature upon the working season.

2.2.2. Churning of cream: The prepared cream is transferred to the churning location. The churning pan filled up to half of its volume otherwise the churning process will be prolonged. The churn is ventilated frequently by opening the value, this helps to escape the gasses from the churn. Fast churning leads to form small grains of butter. When cream becomes yellowish or whitish, it indicates the formation of butter granules. At this 
stage small butter granules are formed. At this time the cooling unit is working to bring down the temperature of cream. The churning is continued till fat globules attain the size of pea which is observed through the churning pan inlet, the butter must be strained to remove buttermilk using hand pressing and squeezing until acceptable dryness and structure were achieved.

2.2.3. Butter batch production: The cream is churned after temperature treatment and after souring where applicable. Butter is traditionally made in cylindrical, conical, cubical or tetrahedral churns with adjustable speed. The shape, setting and size of the cream batch in relation to the churning speed are factors that have an important effect on the end product. Modern churns have a speed range that permits selection of the most suitable working speed for any set of butter parameters.

2.3.4. Butter formation: Manufacturing steps that influence the body and texture of butter include (1) time and temperature of the cream; (2) churning temperature; (3) extent of working; (4) the method of adding coloring and salt; and (5) the manufacturing equipment and churning methods used.

2.3.5. Experimental methodology: The present study was conducted to investigate the relation between cream loading ratio into the churning pan, churning temperature and churning time at constant fan rotating speed of the disc stuck separator and their effect on butter production, butter fat percentage, churning efficiency, specific energy and operational cost. The constructed churning machine was evaluated using the following parameters:

- Cream loading ratio: $25,35,45$ and $55 \%(5,7,9$ and $11 \mathrm{~kg})$.

- Churning temperature: $4,6,8$ and $10{ }^{\circ} \mathrm{C}$.

- Churning time: 5, 10, 15 and $20 \mathrm{~min}$.

\subsection{MEASUREMENTS AND DETERMINATIONS:}

Evaluation of the performance of the constructed churning machine was based on the following indicators:

3.1.1. Butter production, (BPro.):

$$
B_{\text {Pro. }}=\frac{B_{M}}{t}, \quad k g / h
$$

Where: $\mathrm{B}_{\mathrm{M}}=$ Mass of butter in the cream sample, $(\mathrm{kg})$.

$\mathrm{t}=$ Time consumed in the churning process, $(\mathrm{h})$. 
PROCESS ENGINEERING

\subsubsection{Buttermilk production, (BMPro.):}

$$
B M_{\text {Pro. }}=\frac{B M_{M}}{t}, \quad \mathrm{~kg} / \mathrm{h}
$$

Where: $\mathrm{BM}_{\mathrm{M}}=$ Mass of buttermilk in the sample, $(\mathrm{kg})$.

$\mathrm{t}=$ Time consumed in the churning process, $(\mathrm{h})$.

\subsubsection{Butter fat percentage, $\left(B_{F}\right)$ :}

Butter fat percentage was determined according to Gerber's method (1891).

\subsubsection{Buttermilk fat percentage, $(\mathrm{BM})$ :}

Buttermilk fat percentage was determined according to Gerber's method (1891).

\subsubsection{Churning efficiency, ( $\eta$ Churn.):}

$$
\eta_{\text {Churn }}=\frac{B_{\text {Am. }}}{B_{\text {Total }}}, \quad \%
$$

Where:

$\mathrm{B}_{\text {Total }}=$ Mass of butter in the sample, $(\mathrm{kg})$.

$$
\mathrm{B}_{\text {Total }}=\mathrm{B}_{\mathrm{Am} .}+\mathrm{B}_{\mathrm{L}}
$$

Where: $\mathrm{B}_{\mathrm{L}}=$ Mass of butter loss in the buttermilk, $(\mathrm{kg})$.

\subsubsection{Required power, (Po):}

The required power was estimated with the following formula. (Jon Ashby, 1988).

$$
\mathrm{Po}=\sqrt{3} \times \cos \varphi \times \mathrm{I} \times \mathrm{V}
$$

Where: Po $=$ Power required, $\mathrm{kW} \quad \mathrm{I}=$ Current intensity, Ampere

$$
\mathrm{V}=\text { Voltage, }(380 \mathrm{v}) \quad \cos \varphi=0.70
$$

\subsubsection{Specific energy:}

Specific energy for the churning process can be calculated as follows:

$$
E_{\text {Churn }}=\frac{P o}{B_{\text {Am. }}}, \quad k W . h / k g
$$

\subsubsection{Operational cost:}

The operational cost required for the churning process was estimated using the following equation: (Awady, et al. 1982).

$$
C_{\text {op. }}=\frac{\mathrm{C}}{\mathrm{B}_{\text {Pro. }}}, \quad \text { L.E } / \mathrm{kg}
$$


PROCESS ENGINEERING

Where: $\mathrm{C}=$ Hourly cost, L.E/h.

The hourly cost of churning process was determined using the following equation: (Awady, 1978).

$$
\mathrm{C}=\frac{\mathrm{p}}{\mathrm{h}}\left(\frac{1}{\mathrm{a}}+\frac{\mathrm{i}}{2}+\mathrm{t}+\mathrm{r}\right)+(\mathrm{W} . \mathrm{e})+\frac{\mathrm{m}}{144}, \quad \text { L.E } / \mathrm{h}
$$

Where:

$\mathrm{p}=$ price of machine, L.E.

$\mathrm{a}=$ life expectancy, $\mathrm{h}$.

$\mathrm{t}=$ taxes, over heads ratio.

$\mathrm{W}=$ power of motor in $\mathrm{kW}$.

$\mathrm{e}=$ hourly cost $/ \mathrm{kW} \cdot \mathrm{h}$ $\mathrm{h}=$ yearly working hours, h/year

$\mathrm{i}=$ interest rate/year

$\mathrm{r}=$ repairs and maintenance ratio

$\mathrm{m}=$ monthly average wage, $\mathrm{L}$.E.

$144=$ monthly working hours.

\section{RESULTS AND DISCUSSION}

The obtained results will be discussed under the following items:

\subsection{Influence of churning temperature and churning time on butter and buttermilk production:}

Considering the effect of churning temperature, Fig.3 show that increasing churning temperature from 4 to $6{ }^{\circ} \mathrm{C}$, measured at different cream loading ratios of $25,35,45$ and $55 \%$, increased butter production from 13.10 to 15.00 , from 15.80 to 17.65 , from 18.20 to 20.63 and from 19.00 to 21.20 $\mathrm{kg} / \mathrm{h}$, any further increase in churning temperature more than 6 to $10^{\circ} \mathrm{C}$ the butter production decreased from 15.00 to 10.50 , from 17.65 to 12.25 , from 20.63 to 14.00 and from 21.20 to $14.80 \mathrm{~kg} / \mathrm{h}$ at the same previous conditions.
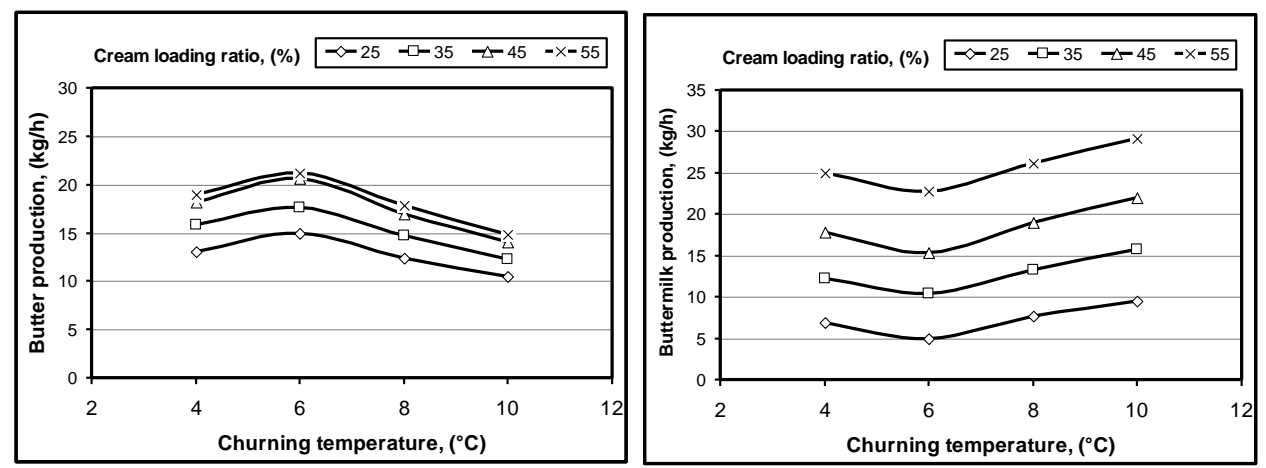

Fig.3. Effect of churning temperature on butter and buttermilk production at different cream loading ratios. 
On the other hand, increasing churning temperature from 4 to $6{ }^{\circ} \mathrm{C}$ at the same previous cream loading ratios, the buttermilk production decreased from 6.90 to 5.00 , from 12.20 to 10.35 , from 17.80 to 15.37 and from 25.00 to $22.80 \mathrm{~kg} / \mathrm{h}$, respectively.

While the further increase in churning temperature from 6 to $10{ }^{\circ} \mathrm{C}$, the buttermilk increased from 5.00 to 9.50 , from 10.35 to 15.75 , from 15.37 to 22.00 and from 22.80 to $29.20 \mathrm{~kg} / \mathrm{h}$, respectively at constant churning time of $15 \mathrm{~min}$. Higher values of churning temperature more than the optimum value tend to decrease butter production because the time required to make butter from the cream was inadequate due to increase of churning force resulting in less butter production and more buttermilk amount with higher percentage of fat. The fat globules must contain the correct proportions of liquid and crystallized fat in order to obtain a firm butter. Warm cream contains liquid fat, which makes whipping difficult. Cream for whipping must therefore be whipped at a low temperature $\left(4-6^{\circ} \mathrm{C}\right)$ over a relatively long period of time to obtain proper crystallization of the fat.

Fig.4. shows the effect of churning time on butter and buttermilk production. Increasing in churning time from 5 to 15 min measured at different cream loading ratios of $25,35,45$ and $55 \%$, leads to increase butter production from 9.10 to 15.00 , from 11.00 to 17.65 , from 12.60 to 20.63 and from 13.00 to $21.20 \mathrm{~kg} / \mathrm{h}$. While the buttermilk production decreased from 10.90 to 5.00 , from 17.00 to 10.35 , from 23.40 to 15.37 and from 31.00 to 22.80 $\mathrm{kg} / \mathrm{h}$, respectively.
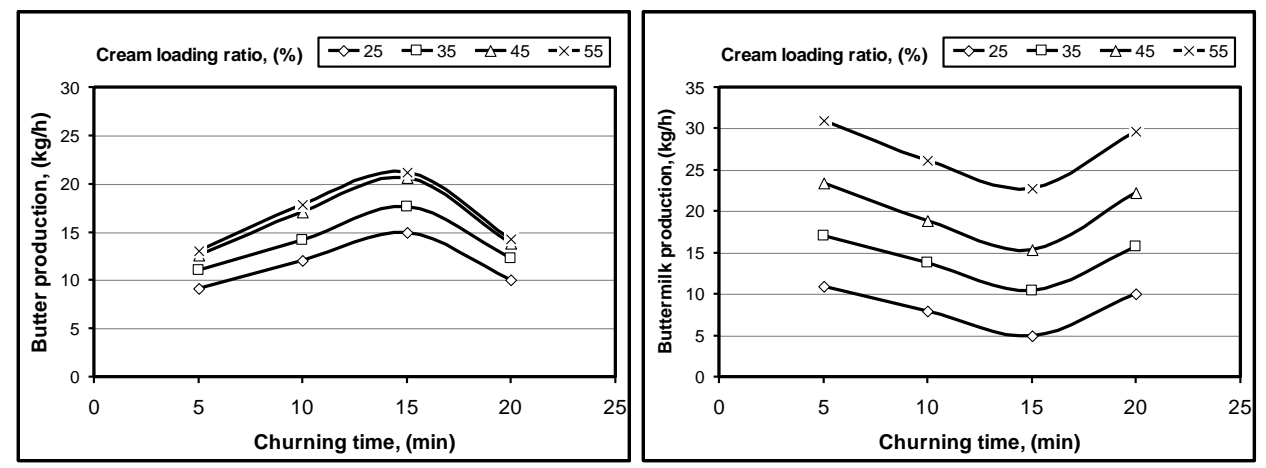

Fig.4. Effect of churning time on butter and buttermilk production at different cream loading ratios.

On the other hand, increasing churning time from 15 to $20 \mathrm{~min}$ at the same previous cream loading ratios, the butter production decreased from 15.00 to 
10.00 , from 17.65 to 12.30 , from 20.63 to 13.80 and from 21.20 to 14.30 $\mathrm{kg} / \mathrm{h}$, while the buttermilk production increased from 5.00 to 10.00 , from 10.35 to 15.70 , from 15.37 to 22.20 and from 22.80 to 29.70 , respectively at constant churning temperature of $6{ }^{\circ} \mathrm{C}$. Higher values of churning time more than the optimum value of $15 \mathrm{~min}$ tend to decrease butter production because of increasing the percentage of small fat globules which go towards the buttermilk, do not have time to integrate of butter clusters, this period is called ripening time.

\subsection{Influence of churning temperature and churning time on butter fat and buttermilk fat percentages:}

Regarding the effect of churning temperature on butter fat and buttermilk fat percentages, Fig. 5 shows that increasing churning temperature from 4 to 6 ${ }^{\circ} \mathrm{C}$ measured at different cream loading ratios of $25,35,45$ and $55 \%$, increased butter fat percentage from 80.60 to 81.20 , from 82.20 to 83.10 , from 84.10 to 85.80 and from 81.40 to $82.50 \%$, any further increase in churning temperature more than 6 up to $10{ }^{\circ} \mathrm{C}$ the butter fat percentage decreased from 81.20 to 76.00 , from 83.10 to 78.30 , from 85.80 to 80.00 and from 82.50 to $77.10 \%$ at the same previous conditions.
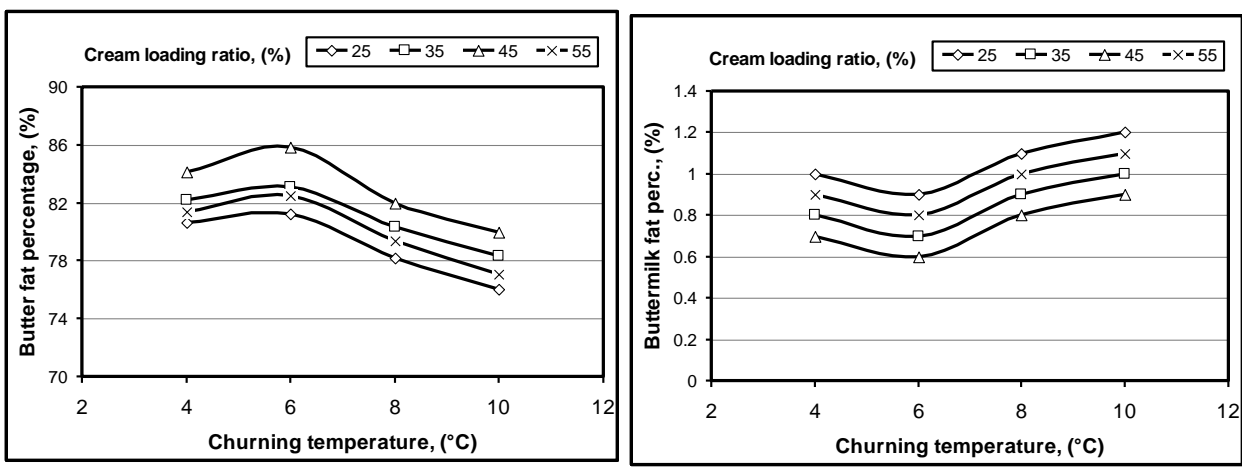

Fig.5. Effect of churning temperature on butter fat and buttermilk fat percentages at different cream loading ratios.

On the other hand, increasing churning temperature from 4 to $6{ }^{\circ} \mathrm{C}$ at the same previous cream loading ratios, the buttermilk fat percentage decreased from 1.00 to 0.90 , from 0.80 to 0.70 , from 0.70 to 0.60 and from 0.90 to $0.80 \%$, respectively. While the increase in churning temperature from 6 to $10{ }^{\circ} \mathrm{C}$ the buttermilk fat percentage increased from 0.90 to 1.20 , from 0.70 to 1.00 , from 0.60 to 0.90 and from 0.80 to $1.10 \%$, respectively at constant churning time of $15 \mathrm{~min}$. 
Relating to the effect of churning time on butter fat and buttermilk fat percentages, Fig. 6 indicated that the increase in churning time from 5 to 15 min measured at different cream loading ratios of $25,35,45$ and $55 \%$, led to increase butter fat percentage from 75.20 to 81.20 , from 77.00 to 83.10 , from 79.50 to 85.80 and from 76.00 to $82.50 \%$.

While the buttermilk fat percentage decreased from 1.30 to 0.90 , from 1.10 to 0.70 , from 1.00 to 0.60 and from 1.20 to $0.80 \%$, respectively. On the other hand, increasing churning time from 15 to $20 \mathrm{~min}$ at the same previous cream loading ratios, the butter fat percentage decreased from 81.20 to 76.50 , from 83.10 to 78.20 , from 85.80 to 80.60 and from 82.50 to $77.20 \%$, while the buttermilk fat percentage increased from 0.90 to 1.20 , from 0.70 to 1.00 , from 0.60 to 0.90 and from 0.80 to $1.10 \%$, respectively at constant churning temperature of $6{ }^{\circ} \mathrm{C}$.
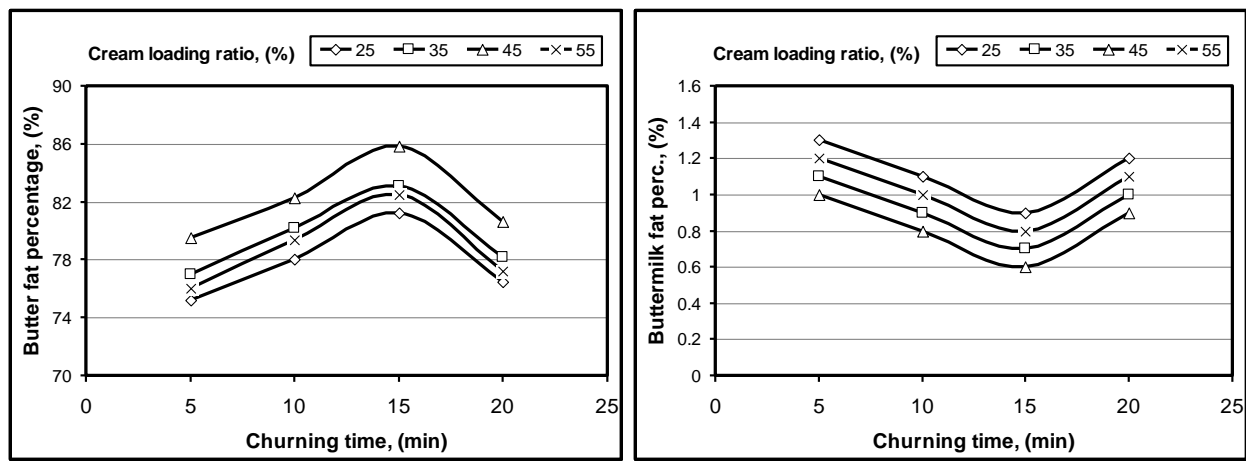

Fig.6. Effect of churning time on butter fat and buttermilk fat percentages at different cream loading ratios.

Higher values of churning temperature more than the optimum value during whipping tend to an inferior froth (butter may be formed in the worst case). The fat globules must contain the correct proportions of liquid and crystallized fat in order to obtain a firm butter in optimum temperature. On the other hand, higher values of churning time more than the optimum value tend to decrease butter fat percentage because cream is subjected to excessive mechanical effect, the fat globule membranes will be damaged tend to decrease butter fat percentage.

\subsection{Influence of churning temperature and churning time on churning efficiency:}

Representative values of churning efficiency for the constructed churn machine versus churning temperature and churning time at different cream 
loading ratios are given in Fig.7. With respect to the effect of churning temperature, results show that increasing churning temperature from 4 to 6 ${ }^{\circ} \mathrm{C}$, measured at different cream loading ratios of $25,35,45$ and $55 \%$, increased churning efficiency from 98.88 to 98.90 , from 99.04 to 99.16 , from 99.17 to 99.31 and from 98.91 to $99.04 \%$, consecutively. Any further increase in churning temperature more than 6 up to $10^{\circ} \mathrm{C}$ at the same cream loading ratios decreased the churning efficiency from 98.90 to 98.45 , from 99.16 to 98.74 , from 99.31 to 98.89 and from 99.04 to $98.59 \%$, respectively at constant churning time of $15 \mathrm{~min}$.
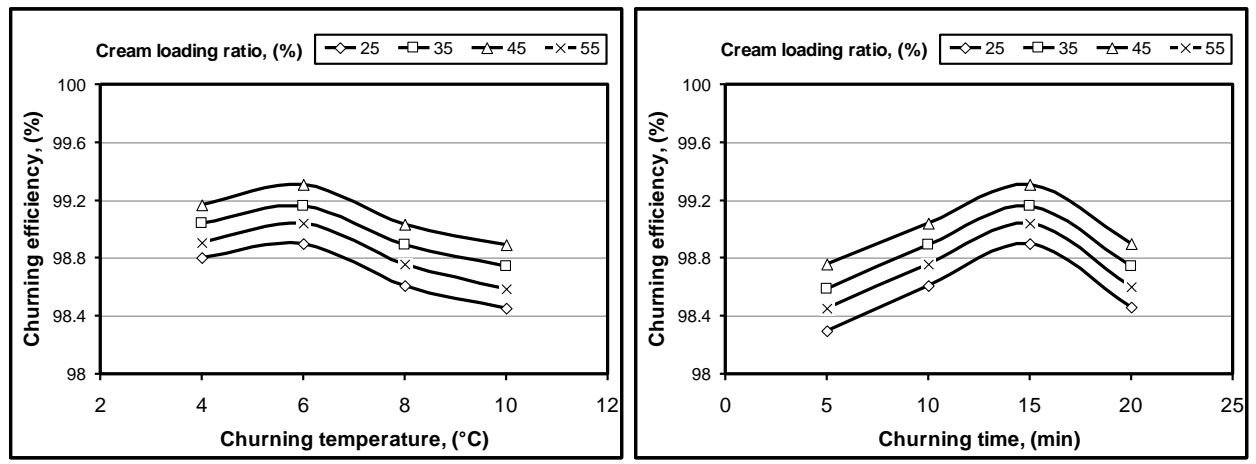

Fig.7. Effect of churning temperature and churning time churning efficiency at different cream loading ratios.

In relation to the effect of churning time on churning efficiency, results in Fig.7 show that increasing churning time from 5 to 15 min measured at different cream loading ratios of $25,35,45$ and $55 \%$, increased churning efficiency from 98.30 to 98.90 , from 98.59 to 99.16 , from 98.76 to 99.31 and from 98.45 to $99.04 \%$, consecutively. In spite of increasing churning time from 15 to $20 \mathrm{~min}$, measured at the same previous cream loading ratios, decreased churning efficiency from 98.90 to 98.46 , from 99.16 to 98.74 , from 99.31 to 98.90 and from 99.04 to $98.60 \%$, respectively, at constant churning temperature of $6{ }^{\circ} \mathrm{C}$.

The highest value of churning efficiency of $99.31 \%$ was recorded at the optimum value of churning temperature of $6{ }^{\circ} \mathrm{C}$ and churning time of 15 min because of mentioned conditions give the fat globules to be collected and discharged through the cream outlet. Under this condition the buttermilk fat percentage was decreased at the lowest value of $0.60 \%$ because these 
conditions give the fat the necessary crystalline structure for optimum butter consistency take place simultaneously in the ripening tanks

\subsection{Influence of churning temperature and churning time on specific energy:}

Concerning the effect of churning temperature, Fig. 8 show that increasing churning temperature from 4 to $6{ }^{\circ} \mathrm{C}$, measured at different cream loading ratios of $25,35,45$ and $55 \%$, decreased specific energy from 37.40 to 32.67, from 31.01 to 27.76, from 26.92 to 23.75 and from 25.79 to 23.11 $\mathrm{kW} . \mathrm{h} / \mathrm{Mg}$, any further increase in churning temperature more than 6 up to 10 ${ }^{\circ} \mathrm{C}$ measured at the same previous cream loading ratios the specific energy increased from 32.67 to 46.67 , from 27.76 to 40.00 , from 23.75 to 35.00 and from 23.11 to $33.11 \mathrm{~kW} . \mathrm{h} / \mathrm{Mg}$ at constant churning time of $15 \mathrm{~min}$.
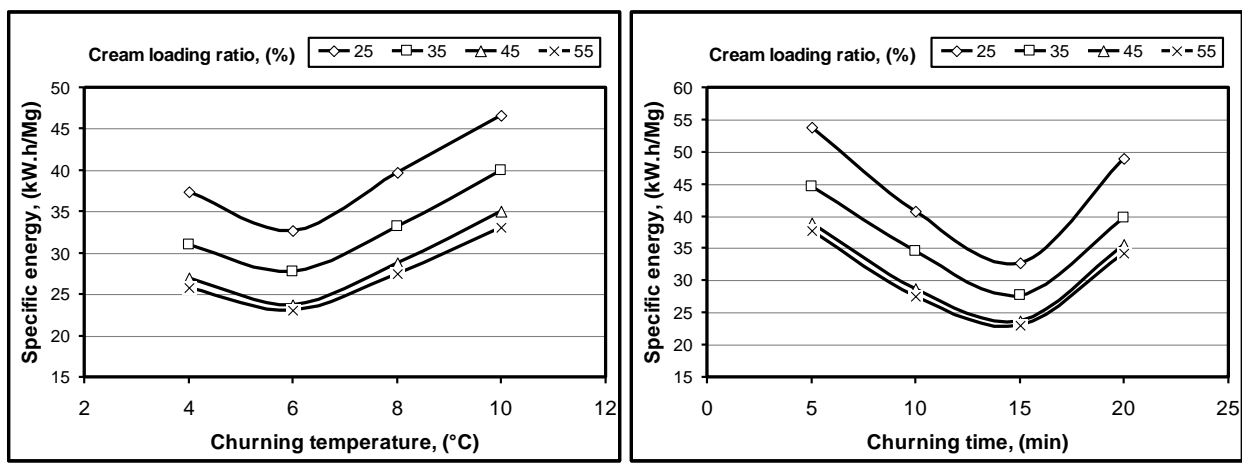

Fig.8. Effect of churning temperature and churning time on specific energy at different cream loading ratios.

With respect to the effect of churning time on specific energy, results in Fig.8 show that increasing churning time from 5 to 15 min measured at different cream loading ratios of $25,35,45$ and $55 \%$, decreased specific energy from 53.85 to 32.67 , from 44.55 to 27.76 , from 38.89 to 23.75 and from 37.69 to $23.11 \mathrm{~kW} . \mathrm{h} / \mathrm{Mg}$, respectively. In spite of increasing churning time from 15 to $20 \mathrm{~min}$, measured at the same previous cream loading ratios, the specific energy increased from 32.67 to 49.00 , from 27.76 to 39.84 , from 23.75 to 35.51 and from 23.11 to $34.27 \mathrm{~kW} . \mathrm{h} / \mathrm{Mg}$, respectively, at constant churning temperature of $6{ }^{\circ} \mathrm{C}$. The higher values of churning temperature and churning time more than the optimum values tend to increase the specific energy due to decrease butter production. 


\subsection{Influence of churning temperature and churning time on operational cost:}

Relating to the effect of churning temperature on operational cost, Fig.9 shows that increasing churning temperature from 4 to $6{ }^{\circ} \mathrm{C}$, measured at different cream loading ratios of $25,35,45$ and $55 \%$, decreased operational cost from 304.58 to 266.00 , from 252.53 to 226.06 , from 219.23 to 193.41 and from 210.00 to $188.21 \mathrm{L.E} / \mathrm{Mg}$, any further increase in churning temperature more than 6 up to $10{ }^{\circ} \mathrm{C}$ measured at the same previous cream loading ratios, the operational cost increased from 266.00 to 380.00 , from 226.06 to 325.71 , from 193.41 to 285.00 and from 188.21 to $269.59 \mathrm{~L} . \mathrm{E} / \mathrm{Mg}$ at constant churning time of $15 \mathrm{~min}$.
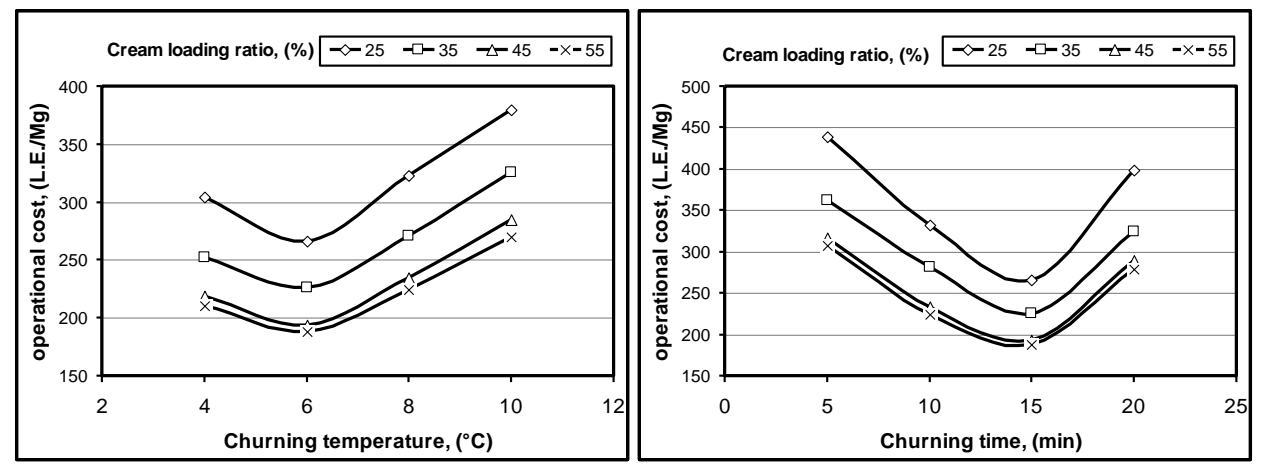

Fig.9. Effect of churning temperature and churning time on operational cost at different cream loading ratios.

Concerning the effect of churning time on operational cost, Fig.9 shows that increasing churning time from 5 to 15 min measured at different cream loading ratios of $25,35,45$ and $55 \%$, decreased operational cost from 438.46 to 266.00 , from 362.73 to 226.06 , from 316.67 to 193.41 and from 306.92 to $188.21 \mathrm{~L} . \mathrm{E} / \mathrm{Mg}$, any further increase in churning time from 15 to $20 \mathrm{~min}$, measured at the same previous cream loading ratios, the operational cost increased from 266.00 to 399.00 , from 226.06 to 324.39 , from 193.41 to 289.13 and from 188.21 to 279.02 L.E/Mg at constant churning temperature of $6{ }^{\circ} \mathrm{C}$.

Both higher and lower values of churning temperature and churning time more than or less to the optimum values tend to increase operational cost due to the decrease in the butter production. 


\section{CONCLUSION}

A butter churning machine for butter and buttermilk production from fermented cream was constructed from locally available materials in a private workshop in Zagazig city and evaluated at Agricultural Engineering Department and Food Science Department under laboratory conditions. The obtained laboratory tests reveal that the butter production value was maximum $(20.63 \mathrm{~kg} / \mathrm{h})$, while the specific energy and operational cost were minimum (23.75 kW.h/Mg and 193.41 L.E/Mg), respectively, under the following conditions:

- Cream loading ratio of $45 \%$ from the butter pan volume of the constructed churning machine.

- Cream temperature of $6^{\circ} \mathrm{C}$ during churning process.

- Churning time of 15 minute for butter and buttermilk production.

\section{REFERRENCES}

Awady, M. N. (1978): Tractor and farm machinery. Text book, Faculty of Agriculture, Ain-Shams University. Pp: 164-167.

Awady, M. N; E. Y. Ghoniem, and A. I. Hashish (1982): Agriculture comparison between wheat combine harvesters under Egyptian conditions. Res. Bul. Ain-Shams Univ.:13p.

Belitz, H. D; W. Grosch and P. Schieberle (2009): 10 Milk and Dairy Products. Food Chemistry. (C) Springer-Verlag Berlin Heidelberg 2009. Pp: 524-526.

Boode, K; P. Walstra and AEA. de Groot-Mostert (1993): Partial coalescence in oil-in-water emulsions. 2. Influence of the properties of the fat. Colloid Surf A 81:139-51.

Food Process Engineering and Technology (FPET) (2013): Butter churn and butter making accessories. Arm field Limited Bridge House, West Street Ringwood, Hampshire, England. http://www.armfield.co.uk.

Frede E. and W. Buchheim (1994): Buttermaking and the churning of blended fat emulsions. J Soc Dairy Techno 47:17-27.

Gerber, N. (1891): Neuer Butyrometer. Patent CH2621, (1891-01-31), Bern: Eidgenössisches Institut für Geistiges Eigentum. 
John G. Ashby (1988): Power Hydraulics. PAVIC Publications.

Marangoni, AG. and SE. McGauley (2003): The relationship between crystallization behavior and structure in cocoa butter. Cryst Growth Des 3:95-108.

\section{Rønholt, S; JJK Kirkensgaard, K. Mortensen and JC. Knudsen (2012):} Effect of cream cooling rate and water content on butter microstructure during four weeks of storage. Food Hydrocolloid.

Rønholt, S; K. Mortensen and J. C. Knudsen (2013): The effective factors on the structure of butter and other milk fat-based products. Article first published online: 10 SEP 2013. Institute of Food Technologists. http://onlinelibrary.wiley.com

Wikipedia (2013): Churning Butter. http://en.wikipedia.org/wiki /Churning_(butter).

Wright, A; MG. Scanlon, RW. Hartel and AG. Marangoni (2001): Rheological properties of milkfat and butter. J Food Sci 66:1056-71.

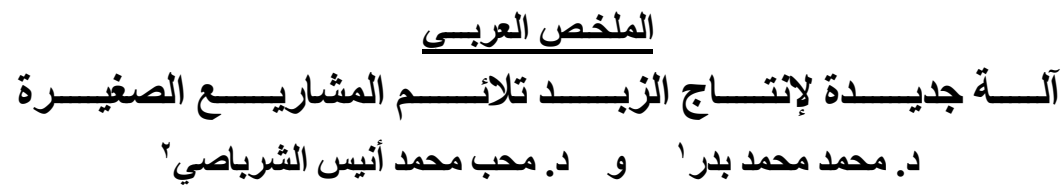

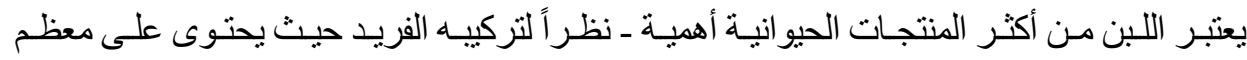

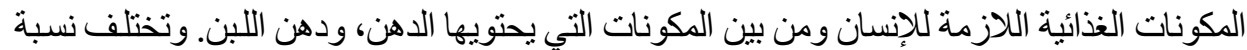

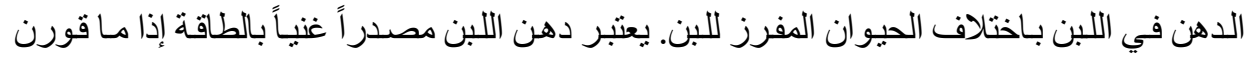

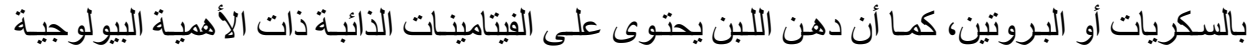

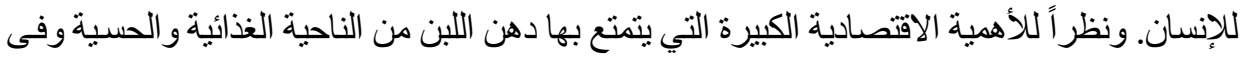

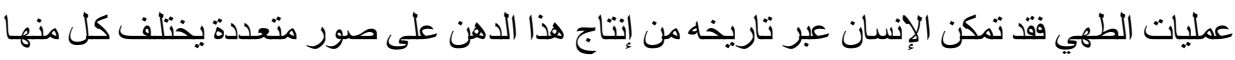

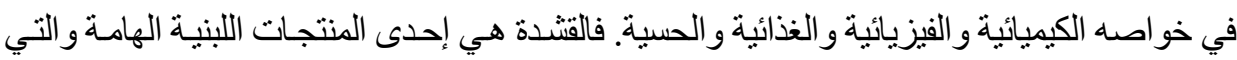

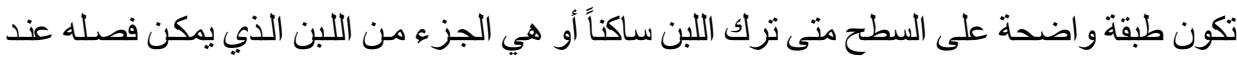

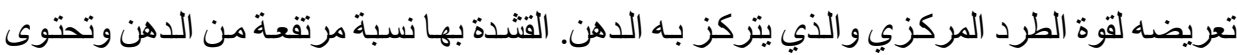

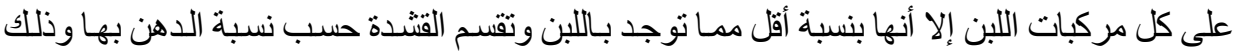

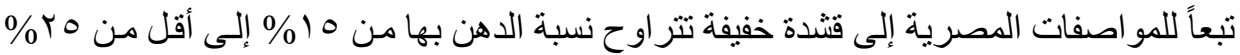

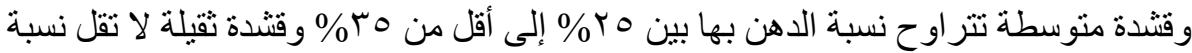

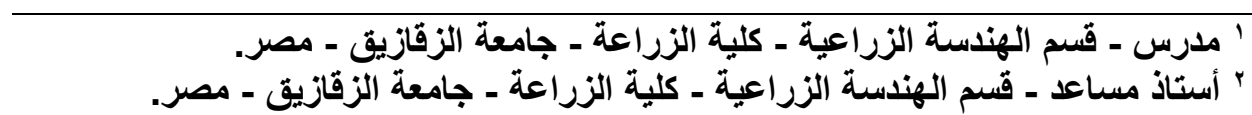


الدهن بها عن 0\%\%. الزبد هو المنتج الدهني الناتج من معاملة اللبن أو القثندة بالطرق اليدوية أو

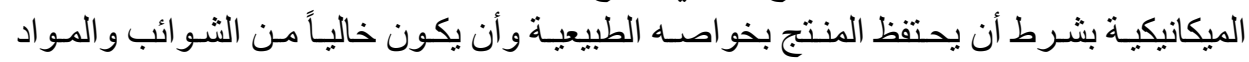

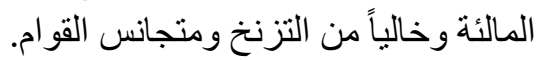

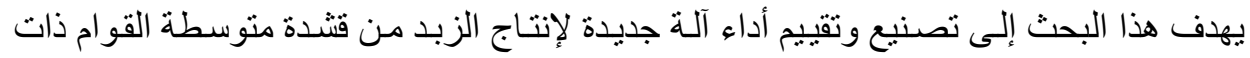

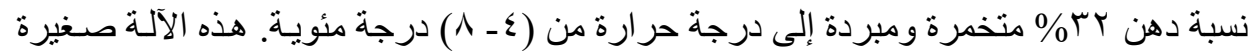

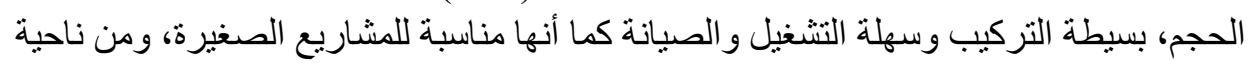

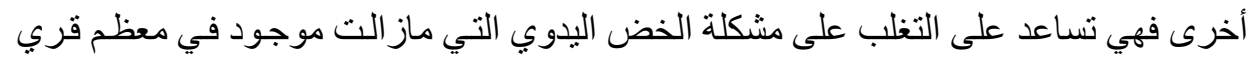
الريف المصري مما يؤدي إلى توفير النفقات وتجنب التكاليف النيف العالية.

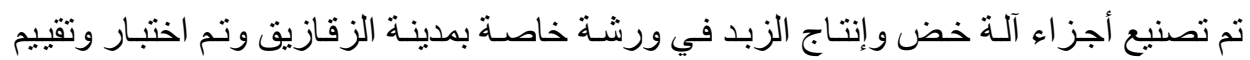

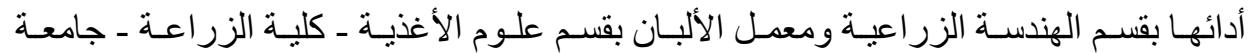
الزقازيق. تتكون الآلة المصنعة من وحدتين رئيسيتين هما: أ. وحدة الخض الميكانيكي: وهي تتكون من الأجز اء الآتية:

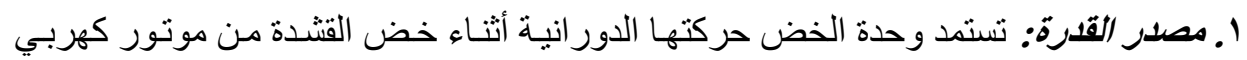

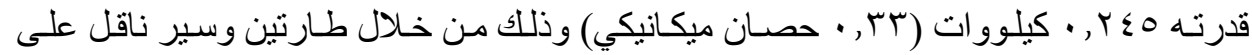

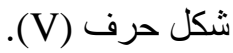

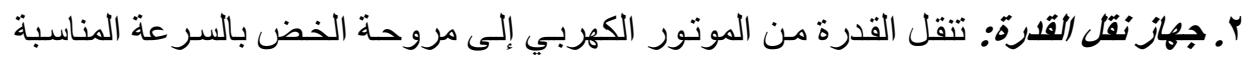

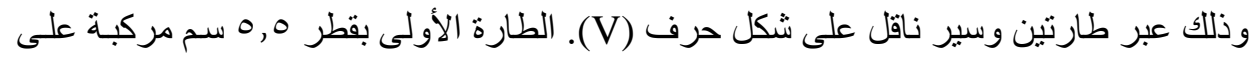

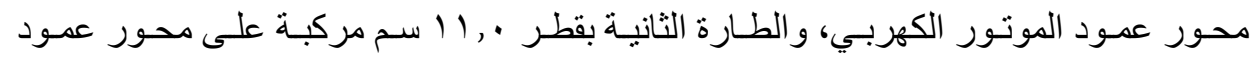

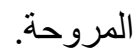

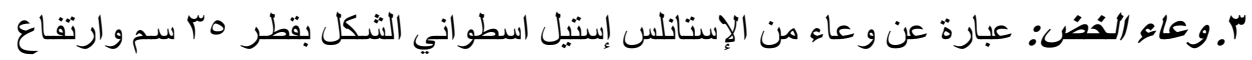

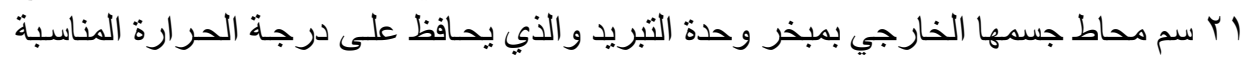

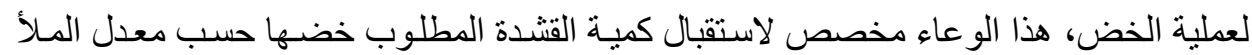

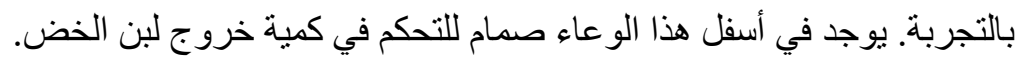

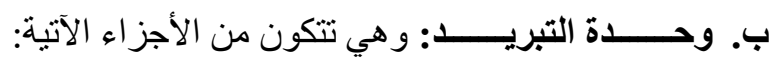
الضاغط - المكثف - صمام التمدد - المبخر.

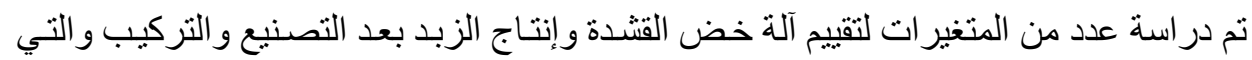

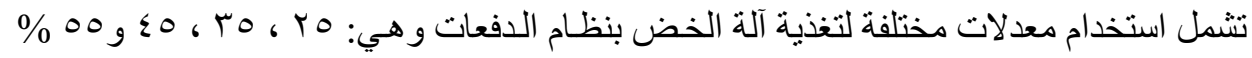

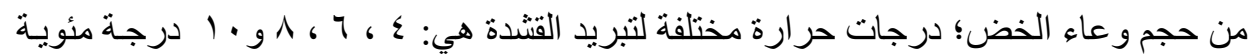

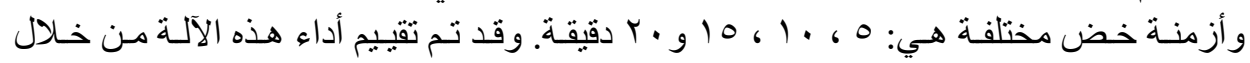

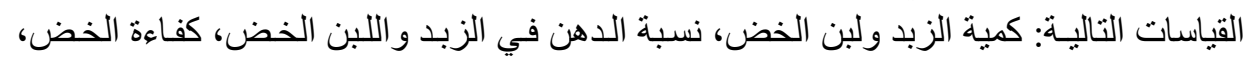
الطاقة النو عية المستهلكة وتكاليف التشغيل اللازمة لعملية الخض و إنتاج الزبد. 


\section{وقد أظهرث النتائج المتحصل عليها ما يلي:}

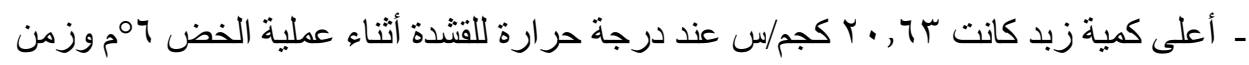

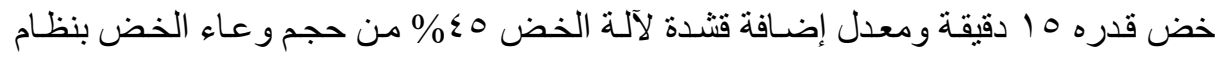
الدفعات.

ـ ـ أعلى كفاءة للآلة أثناء خض القشدة و إنتاج الزبد كانت اس, 99\% عند درجـة حرارة للقشدة أثناء عملية الخض اعلى كفاع وزمن خض قدره 10 دقيقة ومعدل إضـافة قثدة لآلة الخض من حجم و عاء الخض بنظام الدفعات.

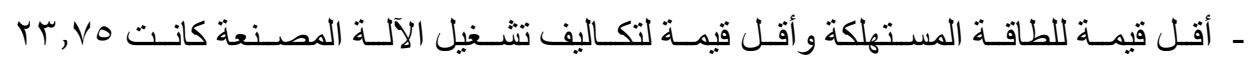

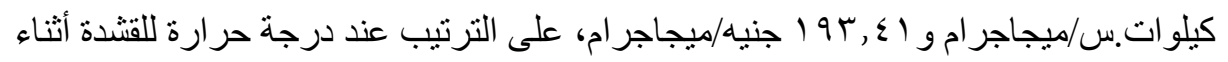

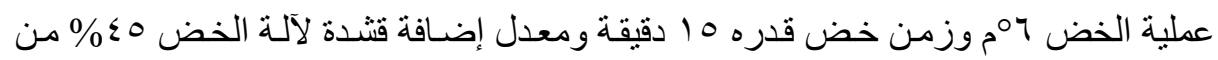
حجم و عاء الخض بنظام الدفعات.

- وبالتالي يوصى باستخدام آلة الخض المصنعة محلياً لإنتاج الزبد والحصول على أعلى كمية منه بأقل طاقة مستهلكة وأقل تكاليف تشغيل عند الظروف التالية:

- معدل إضافة قثدة متخمرة ومبردة إلى الآلة بنظام الدفعات عند 0 ؛\% من حجم و عاء الخض. - زمن خض قدره 10 دقيقة لإنتاج الزبد بالو اصفات القياسية. - درجة حر ارة للقشدة أثناء الخض قدرها بوم. 